\title{
Direct Electrochemical Synthesis of Pyrimidine-2-thionato Complexes of Zinc(II) and Cadmium(II): The Crystal Structure of (1,10-Phenanthroline)bis(pyrimidine-2-thionato)cadmium(II)
}

\author{
R. Castro, M. L. Durán, J. A. García-Vázquez, J. Romero, and A. Sousa* \\ Departamento de Química Inorgánica, Universidad de Santiago, \\ Santiago de Compostela, Spain
}

\begin{abstract}
A. Castiñeiras, W. Hiller, and J. Strähle
Institut für Anorganische Chemie der Universität Tübingen,

Auf der Morgenstelle 18, D-W-7400 Tübingen, Germany

Z. Naturforsch. 47b, 1067-1074 (1992); received January 27, 1992

$\mathrm{X}$-Ray, Cadmium Complexes, Pyrimidine-2-thione, Zinc Complexes

$\mathrm{Zn}$ (pymt $)_{2}$ and $\mathrm{Cd}(\text { pymt })_{2}$ complexes have been obtained by electrochemical oxidation of anodic zinc or cadmium in acetonitrile solutions of pyrimidine-2-thione (Hpymt). When 2,2'bipyridine (bipy) or 1,10-phenanthroline (phen) was added to the electrochemical cell, the adducts $\left[\mathrm{M}(\text { pymt })_{2}(\right.$ bipy $\left.)\right]$, or $\left[\mathrm{M}(\text { pymt })_{2}(\mathrm{phen})\right](\mathrm{M}=\mathrm{Zn}$ or $\mathrm{Cd})$ were obtained. Crystals of [Cd(pymt) ${ }_{2}$ phen] are orthorhombic, with $a=9.882(2), b=12.491(1), c=16.513(2) \AA$, space group $\mathrm{P} 2_{1} 2_{1} 2_{1}$ and $Z=4$. The cadmium atom has distorted octahedral geometry, and one nitrogen atom of each pyrimidine-2-thiolato ligand is not coordinated.
\end{abstract}

A number of important biological compounds [1], notably purine and pyrimidine bases and their sulphur-containing analogues exhibit tautomeries of the kind

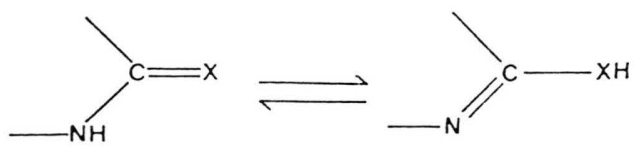

$(\mathrm{X}=\mathrm{O}$ or $\mathrm{S})$. This has stimulated interest in the coordination chemistry of such ligands. Pyrimidine-2-thione is one of the simplest examples and one of the most versatile and unique; the neutral species (pymtH) can act either as a monodentate ligand through the sulphur atom [2] (A) or as a chelating ligand [3] (B); while the anion pymt ${ }^{-}$can act as a monodentate through the sulphur atom [4] (C), as a chelating ligand [5-7] (D), as a bridging ligand through nitrogen and sulphur $[4,8](E)$, and as a bridging ligand between three metal atoms [9] (F).

We recently reported a series of zinc(II), cadmium(II) [10] and nickel(II) [11] pyridine2-thionato complexes and nickel(II) pyrimidine2-thionato complexes [12]. In this paper we de-

\footnotetext{
* Reprint requests to Prof. Dr. Antonio Sousa.

Verlag der Zeitschrift für Naturforschung,

D-W-7400 Tübingen

$0932-0776 / 92 / 0800-1067 / \$ 01.00 / 0$
}<smiles></smiles>

(A)<smiles>[M]C1NC2=NC=CC=CN21</smiles>

(D)<smiles>[M]C1Nc2cccnc2S1</smiles>

(8)<smiles>[M]SC1=NC=CCN1[M]</smiles>

(E)<smiles>[M]Sc1ncccn1</smiles>

(c)<smiles>[M]c1ccnc([M])c1[M]</smiles>

(F) scribe the electrochemical synthesis and properties of $\mathrm{ML}_{2}$ pyrimidine-2-thionato complexes of zinc(II) and cadmium(II), and of several ternary complexes of these metals incorporating pyrimidine-2-thionato and phenanthroline or bipyridine as coligands. The crystal structure of 1,10-phenanthroline-bis(pyrimidine-2-thionato)cadmium(II) is also described; this compound, as far as we know, is the first example of an octahedral metal complex containing two bidentate pyrimidine-2-thionato li- 
gands with the sulphur atoms "cis", which contrast with the "trans" disposition found in the other complexes.

\section{Experimental}

Acetonitrile was distilled before use. Pyrimidine-2-thione $\quad(\mathrm{pymtH}), \quad$ 1,10-phenanthroline (phen) and 2,2'-bipyridine (bipy) (Aldrich) were used as supplied. Zinc and cadmium (Aldrich) were used in the form of plates $0.5 \mathrm{~mm}$ thick that were washed with dilute nitric acid solution followed by distilled water and then dried before use.

\section{Physical measurements}

The $\mathrm{C}, \mathrm{N}$ and $\mathrm{H}$ contents of the complexes were determined on a Carlo Erba EA 1108 microanalyser. Infrared spectra were recorded in $\mathrm{KBr}$ mulls on a Perkin-Elmer 180 spectrophotometer. ${ }^{1} \mathrm{H}$ NMR spectra were recorded on a Bruker WM 250 $\mathrm{MHz}$ using DMSO- $\mathrm{d}_{6}$ as solvent. The chemical shifts were determined against TMS as internal standard.

\section{Electrochemical procedures}

The electrochemical method used for synthesis was similar to that described by Tuck and co-workers [13]. The cell was a $100 \mathrm{~cm}^{3}$ tall beaker fitted with a rubber bung through which the electrochemical leads passed. The anode ( $\mathrm{Zn}$ or $\mathrm{Cd})$ was suspended from a platinum wire and the cathode was also a platinum wire. All experiments were carried out under a dry nitrogen atmosphere, which also served to stir the reaction mixture as it bubbled through the solution. The ligand pyrimidine-2-thione was dissolved in acetonitrile and a small amount of tetramethylammonium perchlorate was added. For the synthesis of mixed complexes the corresponding coligand, 1,10-phenanthroline or 2,2'-bipyridine, was added to the solu- tion. Direct current was obtained from a purposebuilt d.c. power supply.

Details of the isolation procedures are given below. Experimental conditions for the electrochemical syntheses are set out in Table I, and the analytical results in Table II.

\section{Electrochemical synthesis of $M(\text { pymt })_{2}$ $(M=Z n, C d)$}

The cells used can be summarized as $\mathrm{Pt}(-) /$ $\mathrm{MeCN}+\mathrm{Hpymt} / \mathrm{M}(+)$. During electrolysis the solution was kept at $40-50{ }^{\circ} \mathrm{C}$ in order to keep pyrimidine-2-thione dissolved. The formation of an insoluble product took place within a few minutes. At the end of electrolysis the powdery pale yellowbrown product was collected, washed several times with acetonitrile and ether, and dried in a vacuum. Both products are insoluble in acetone, chloroform and hydrocarbon solvents, but soluble enough in dimethylsulphoxide to run NMR spectra. The IR and NMR spectra both show the presence of pymt ${ }^{-}$in the complexes (see below). The yields of the syntheses, based on the quantity of metal dissolved from the anode, were essentially quantitative.

\section{Electrochemical synthesis of $M($ pymt $){ }_{2} L^{\prime}$ ( $L^{\prime}=$ bipyridine or phenanthroline)}

As electrolysis proceeded, the colour of the solution changed from yellow to brown. No precipitation occurred initially, but within one hour a microcrystalline product appeared at the bottom of the vessel and covering the electrodes. This solid was collected and washed with acetonitrile and ether. The compounds are insoluble in hydrocarbon solvents, slightly soluble in chloroform and acetonitrile, and soluble in DMSO. The IR and NMR spectra confirm the presence of both ligands.

Table I. Experimental conditions for the electrochemical synthesis of $\mathrm{M}(\mathrm{pymt})_{2}$ and $\mathrm{M}(\mathrm{pymt})_{2} \mathrm{~L}^{\prime}\left(\mathrm{M}=\mathrm{Zn}, \mathrm{Cd} ; \mathrm{L}^{\prime}=\right.$ bipy, phen).

\begin{tabular}{lllllll}
\hline Compound & $\begin{array}{l}\text { Amount of } \\
\text { pymtH(g) }\end{array}$ & $\begin{array}{l}\text { Amount of } \\
\mathrm{L}^{\prime}(\mathrm{g})\end{array}$ & $\begin{array}{l}\text { Initial } \\
\text { voltage }^{\mathrm{b}}(\mathrm{v})\end{array}$ & $\begin{array}{l}\text { Time } \\
(\mathrm{h})\end{array}$ & $\begin{array}{l}\text { Metal } \\
\text { dissolved }(\mathrm{mg})\end{array}$ & $\begin{array}{l}\text { Ef } \\
(\mathrm{molF}\end{array}$
\end{tabular}

\footnotetext{
${ }^{\mathrm{a}}$ In $50 \mathrm{ml}$ of acetonitrile plus $20 \mathrm{mg} \mathrm{Et}_{4} \mathrm{NClO}_{4}$; ${ }^{\mathrm{b}}$ voltage required to produce a initial current of $20 \mathrm{~mA}$.
} 
Table II. Analytical data for the complexes.

\begin{tabular}{llll}
\hline & \multicolumn{3}{c}{ Found(calcd) (\%) } \\
\hline Compound & $\mathrm{C}$ & $\mathrm{N}$ & $\mathrm{H}$ \\
\hline $\mathrm{Zn}(\text { pymt })_{2}$ & $32.9(33.4)$ & $19.3(19.4)$ & $2.5(2.1)$ \\
$\mathrm{Zn}\left(\right.$ pymt ${ }_{2}$ bipy $\cdot 3 \mathrm{H}_{2} \mathrm{O}$ & $43.5(43.5)$ & $16.1(16.9)$ & $3.7(4.0)$ \\
$\mathrm{Zn}\left(\right.$ pymt ${ }_{2}$ phen & $51.3(51.4)$ & $18.0(18.0)$ & $3.1(3.0)$ \\
Cd(pymt) & $28.9(28.7)$ & $16.5(16.7)$ & $2.0(1.8)$ \\
Cd(pymt) ${ }_{2}$ bipy $\cdot \mathrm{H}_{2} \mathrm{O}$ & $42.7(42.4)$ & $16.8(16.5)$ & $3.6(3.1)$ \\
Cd(pymt) ${ }_{2}$ phen & $46.5(46.6)$ & $16.6(16.3)$ & $2.7(2.7)$ \\
\hline
\end{tabular}

Pale brown crystals of $\left[\mathrm{Cd}(\mathrm{pymt})_{2}\right.$ phen] suitable for X-ray studies were obtained by slow evaporation of a solution of the compound in acetonitrile.

\section{Determination of the crystal structure of [Cd (pymt $)_{2}$ phen]}

An amber-coloured parallelepipedic crystal of approximate dimensions $0.10 \times 0.25 \times 0.15 \mathrm{~mm}$ was mounted on a glass fibre and used for data collection on a CAD4 Enraf-Nonius four-circle automatic diffractometer. Cell constants (Table III) and an orientation matrix for data collection were obtained by least-squares refinement on the Bragg angles of 25 reflections in the $\theta$-range $19-27^{\circ}$. The

Table III. Crystallographic data for [Cd(pymt $)_{2}$ phen].

\begin{tabular}{ll}
\hline Formula & $\mathrm{C}_{20} \mathrm{H}_{14} \mathrm{CdN}_{6} \mathrm{~S}_{2}$ \\
$\mathrm{M}$ & 514.90 \\
$a[\AA]$ & $9.882(2)$ \\
$b[\AA]$ & $12.491(1)$ \\
$c[\AA]$ & $16.513(2)$ \\
$\alpha[\mathrm{deg}]$ & 90.00 \\
$\beta[\mathrm{deg}]$ & 90.00 \\
$\gamma[\mathrm{deg}]$ & 90.00 \\
Cryst syst & Orthorhombic \\
Space group & $\mathrm{P} 2_{1} 2_{1} 2_{1}$ \\
$\mathrm{~V}\left[\AA^{3}\right]$ & 2038.3 \\
$Z$ & 4 \\
$\mathrm{~d}_{\text {calc, }}$ gcm & -3 \\
$\mathrm{U}\left(\mathrm{CuK} \mathrm{K}_{\alpha}\right)$, cm $^{-1}$ & 1.678 \\
Radiation $\left(\mathrm{CuK}{ }_{\alpha}\right)$ & 108.587 \\
$\mathrm{~F}(000)$ & $\lambda=1.54056 \AA$ \\
min.-max. abs. correction & 1024 \\
max. $($ sin $\theta) / \lambda$ & $0.710-1.810$ \\
Total No. refl. measured & 0.605 \\
$(\theta$ range) & $2174(3-69 \mathrm{deg})$ \\
No. of unique refl. & \\
No. of observ. refl. & 2174 \\
(criterion) & $2027[\mathrm{I}>3 \sigma(\mathrm{I})]$ \\
No. of refined parameter & 263 \\
temp, K & 293 \\
$R$ & 0.057 \\
$R_{\mathrm{w}}$ & 0.062 \\
\hline
\end{tabular}

orthorhombic space group $\mathrm{P} 22_{1} 2_{1} 2_{1}$ was inferred from the systematic absences observed. Data were collected at $293 \mathrm{~K}$ using $\mathrm{CuK} \alpha$ radiation $(\lambda=$ $1.54056 \AA)$ in $\omega / \theta$ scan technique. The data were corrected for Lorentz and polarization effects. An empirical absorption correction [14] and a secondary extinction correction were applied [15] (the final coefficient, refined in the last least-squares cycle, was $\left.1.08(1) \times 10^{-6}\right)$.

The structure was solved by direct methods [16] that revealed the positions of all non-hydrogen atoms, which were all refined anisotropically. The coordinates of the hydrogen atoms were calculated on the basis of geometric arguments, and were included in structure factor calculations with $\mathrm{B}_{\text {iso }}=$ $5.0 \AA^{2}$, but not refined. The structure was refined by full-matrix least-squares [17]; the final $R$ value was 0.057 , with $R_{\mathrm{w}}=0.062$ (weighting scheme $\mathrm{w}^{-1}=\sigma^{2}(\mathrm{~F}) ; 263$ parameters; $\mathrm{S}=2.905$; maximum $\Delta / \sigma$ in final cycle 0.001 ; maximum $\Delta \varrho=$ $1.003 \mathrm{e} \AA^{-3}$ ). Computations were performed on a DECMicroVAX 3500 computer*.

\section{Results and Discussion}

The electrochemical oxidation of $\mathrm{Zn}$ or $\mathrm{Cd}$ in the presence of pyrimidine-2-thione to obtain $\mathrm{M}$ (pymt) $)_{2}$ was simple and efficient; $\mathrm{Zn}(\text { pymt })_{2}$ has already been prepared by alternative routes [3]. In the presence of neutral bidentate donors such as bipyridine or phenanthroline, mixed complexes $\mathrm{M}$ (pymt) ${ }_{2} \mathrm{~L}^{\prime}$ can be obtained in one step. No such compounds appear to have been reported previously.

The average $E_{f}$ (the number of moles of metal dissolved per Faraday of charge) was near to 0.5 mol. $F^{-1}$. This fact and the formation of $\mathrm{H}_{2}$ at the cathode are in keeping with the following mechanism.

$$
\begin{aligned}
& \text { Cathode: } 2 \text { pymt } \mathrm{H}+2 \mathrm{e}^{-} \rightarrow \mathrm{H}_{2}+2 \text { pymt }^{-} \\
& \text {Anode: } 2 \text { pymt }^{-}+\mathrm{M} \rightarrow \mathrm{M}(\text { pymt })_{2} \\
& 2 \text { pymt }^{-}+\mathrm{M}+\mathrm{L}^{\prime} \rightarrow \mathrm{M}(\text { pymt })_{2} \mathrm{~L}^{\prime}
\end{aligned}
$$

\section{Structure of $\mathrm{Cd}\left(\mathrm{SC}_{4} \mathrm{H}_{3} \mathrm{~N}_{2}\right)_{2}\left(\mathrm{C}_{12} \mathrm{H}_{8} \mathrm{~N}_{2}\right)$}

This compounds crystallizes in the orthorhombic space group $\mathrm{P} 22_{1} 2_{1} 2_{1}$. Figure 1 gives a perspec-

\footnotetext{
* Further details of the structure determination have been deposited as Supplementary Publication No CSD 55452. Copies may be obtained through the Fachinformationszentrum Karlsruhe $\mathrm{GmbH}$, D-W-7514 Eggenstein-Leopoldshafen.
} 


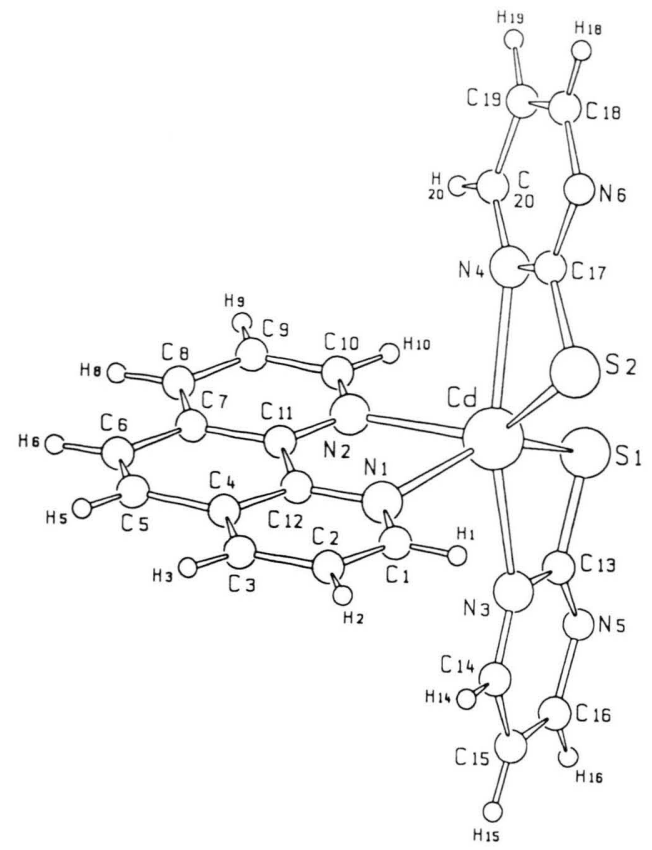

Fig. 1. Perspective view of $\left[\mathrm{Cd}(\mathrm{pymt})_{2}\right.$ phen $]$ showing the numbering cheme.

tive view of the complex [18]. Final atomic coordinates are given in Table IV, and selected bond distances and angles, together with their estimated standard deviations, are listed in Table V.

As can be seen in Fig. 1, monomeric $\mathrm{Cd}\left(\mathrm{SC}_{4} \mathrm{H}_{3} \mathrm{~N}_{2}\right)_{2}\left(\mathrm{C}_{12} \mathrm{H}_{8} \mathrm{~N}_{2}\right)$ has highly distorted octahedral coordination around $\mathrm{Cd}(\mathrm{II})$. The coordination sphere involves two nitrogen atoms of the bidentate phenanthroline ligand, and one sulphur and one nitrogen atom belonging to each of two pyrimidine-2-thiolato ligands, which each form a four-membered chelate ring through one of their nitrogen atoms and the sulphur atom. The arrangement of the two pyrimidine-2-thionato ligands is such that the two sulphur atoms are in a cis arrangement and the two nitrogen atoms trans.

The $\mathrm{Cd}-\mathrm{S}$ bond distances, 2.588(3) and 2.549(3) $\AA$, are slightly shorter than those found in other octahedral cadmium(II) complexes; for example, 2.647(3) and 2.727(3) $\AA$ in

$\left[\mathrm{Cd}\left(\mathrm{S}_{2} \mathrm{COC}_{2} \mathrm{H}_{5}\right)_{2} \cdot\right.$ phen] [19]; 2.655(3)-2.755(3) in the $\left\{\mathrm{Cd}\left[\mathrm{S}_{2} \mathrm{CN}\left(\mathrm{C}_{2} \mathrm{H}_{5}\right)_{2}\right]_{3}\right\}^{-}$anion, 2.658(1)$2.777(2) \AA$ in the $\left\{\mathrm{Cd}\left[\mathrm{S}_{2} \mathrm{P}\left(\mathrm{OC}_{3} \mathrm{H}_{7}\right)_{2}\right]_{3}\right\}^{-}$anion, and 2.667(6) $\AA$ in tetraethylammonium tris(benzothiazole-2-thiolato)cadmate [20]; and 2.664(1) and
Table IV. Positional parameters of all non-hydrogen atoms for [Cd(pymt) ${ }_{2}$ phen].

\begin{tabular}{|c|c|c|c|}
\hline Atom & $x$ & $y$ & $z$ \\
\hline $\mathrm{Cd}$ & $0.14797(8)$ & $0.38975(7)$ & $0.30898(5)$ \\
\hline $\mathrm{S}(1)$ & $0.3928(3)$ & $0.3186(3)$ & $0.3235(2)$ \\
\hline $\mathrm{S}(2)$ & $0.0102(3)$ & $0.4021(3)$ & $0.4392(2)$ \\
\hline$N(1)$ & $-0.0541(9)$ & $0.3988(8)$ & $0.2294(6)$ \\
\hline $\mathrm{N}(2)$ & $0.177(1)$ & $0.5073(8)$ & $0.1981(6)$ \\
\hline$N(3)$ & $0.204(1)$ & $0.2273(8)$ & $0.2361(6)$ \\
\hline $\mathrm{N}(4)$ & $0.186(1)$ & $0.5475(8)$ & $0.4014(7)$ \\
\hline $\mathrm{N}(5)$ & $0.428(1)$ & $0.1546(8)$ & $0.2232(8)$ \\
\hline $\mathrm{N}(6)$ & $0.065(1)$ & $0.577(1)$ & $0.5228(7)$ \\
\hline$C(1)$ & $-0.171(2)$ & $0.349(1)$ & $0.2449(9)$ \\
\hline$C(2)$ & $-0.289(1)$ & $0.369(1)$ & $0.204(1)$ \\
\hline$C(3)$ & $-0.289(1)$ & $0.441(1)$ & $0.1396(9)$ \\
\hline$C(4)$ & $-0.169(2)$ & $0.491(1)$ & $0.1217(8)$ \\
\hline$C(5)$ & $-0.160(2)$ & $0.568(1)$ & $0.0548(9)$ \\
\hline$C(6)$ & $-0.047(2)$ & $0.616(1)$ & $0.0376(8)$ \\
\hline $\mathrm{C}(7)$ & $0.075(1)$ & $0.5973(9)$ & $0.0855(7)$ \\
\hline $\mathrm{C}(8)$ & $0.199(2)$ & $0.648(1)$ & $0.0698(8)$ \\
\hline C (9) & $0.305(1)$ & $0.630(1)$ & $0.1211(9)$ \\
\hline$C(10)$ & $0.291(1)$ & $0.557(1)$ & $0.1846(8)$ \\
\hline $\mathrm{C}(11)$ & $0.071(1)$ & $0.525(1)$ & $0.1504(6)$ \\
\hline $\mathrm{C}(12)$ & $-0.052(1)$ & $0.4686(9)$ & $0.1673(7)$ \\
\hline$C(13)$ & $0.341(1)$ & $0.2227(9)$ & $0.2553(7)$ \\
\hline $\mathrm{C}(14)$ & $0.162(1)$ & $0.154(1)$ & $0.1860(9)$ \\
\hline$C(15)$ & $0.243(2)$ & $0.079(1)$ & $0.148(1)$ \\
\hline$C(16)$ & $0.379(2)$ & $0.084(1)$ & $0.171(1)$ \\
\hline$C(17)$ & $0.092(1)$ & $0.520(1)$ & $0.4547(7)$ \\
\hline $\mathrm{C}(18)$ & $0.144(2)$ & $0.666(1)$ & $0.5345(9)$ \\
\hline C(19) & $0.240(2)$ & $0.700(1)$ & $0.482(1)$ \\
\hline $\mathrm{C}(20)$ & $0.254(2)$ & $0.636(1)$ & $0.413(1)$ \\
\hline
\end{tabular}

2.704(1) $\AA$ in $\left[\mathrm{Cd}\left(\mathrm{S}_{2} \mathrm{CSC}_{4} \mathrm{H}_{9} \text {-n }\right)_{2} \cdot\right.$ bipy] [21]. However, the $\mathrm{Cd}-\mathrm{S}$ bond distances in a series of pentacoordinate and tetra-coordinate compounds are comparable to those observed in the present work: in the penta-coordinate dimers

$\left\{\mathrm{Cd}_{2}\left[\mathrm{~S}_{2} \mathrm{CN}\left(\mathrm{C}_{2} \mathrm{H}_{5}\right)\right]_{4}\right\}$ [22] and $\left\{\mathrm{Cd}_{2}\left[\mathrm{~S}_{2} \mathrm{CN}\left(\mathrm{CH}_{2}\right)_{6}\right]_{4}\right\}$ [23] the $\mathrm{Cd}-\mathrm{S}$ terminal bond distances are in the range $2.53-2.64 \AA$ and the bridging $\mathrm{Cd}-\mathrm{S}$ distance in the range $2.80-2.87 \AA$; and similar values have been reported [24] for several distorted tetrahedral thiolates of the type $\left[\mathrm{Cd}(\mathrm{SR})_{4}\right]^{2-}$, in which the $\mathrm{Cd}-\mathrm{S}$ bond distances lie in the range 2.53$2.56 \AA$. It is thus clear that $\mathrm{Cd}-\mathrm{S}$ bond lengths in $\left[\mathrm{Cd}(\text { pymt })_{2} \cdot\right.$ phen] are somewhat smaller than those generally observed in analogous hexacoordinated cadmium compounds. Moreover, these lengths are even slightly shorter than the $\mathrm{Zn}(\mathrm{II})-\mathrm{S}$ distances, 2.627(2) and 2.546(3) $\AA$, found in octahedral $\left[\mathrm{Zn}(\mathrm{pyt})_{2}\right.$ phen] [10], where $\mathrm{pyt}^{-}$is pyridine2-thiolato. It has been shown that the $\mathrm{M}-\mathrm{S}$ distances in analogous complexes of a given metal 


\begin{tabular}{|c|c|c|c|}
\hline \multicolumn{4}{|c|}{ Bond distances $(\AA)$} \\
\hline $\mathrm{Cd}-\mathrm{S}(1)$ & $2.588(3)$ & $N(6)-C(18)$ & $1.37(2)$ \\
\hline $\mathrm{Cd}-\mathrm{S}(2)$ & $2.549(3)$ & $C(4)-C(5)$ & $1.47(2)$ \\
\hline$C d-N(1)$ & $2.394(9)$ & $C(4)-C(12)$ & $1.41(2)$ \\
\hline $\mathrm{Cd}-\mathrm{N}(2)$ & $2.36(1)$ & $C(5)-C(6)$ & $1.29(2)$ \\
\hline $\mathrm{Cd}-\mathrm{N}(3)$ & $2.42(2)$ & $C(6)-C(7)$ & $1.46(2)$ \\
\hline $\mathrm{Cd}-\mathrm{N}(4)$ & $2.53(2)$ & $C(7)-C(8)$ & $1.40(3)$ \\
\hline $\mathrm{S}(1)-\mathrm{C}(13)$ & $1.72(1)$ & $C(7)-C(11)$ & $1.40(2)$ \\
\hline $\mathrm{S}(2)-\mathrm{C}(17)$ & $1.70(1)$ & $C(8)-C(9)$ & $1.37(2)$ \\
\hline$N(3)-C(13)$ & $1.39(2)$ & $\mathrm{C}(9)-\mathrm{C}(10)$ & $1.40(2)$ \\
\hline$N(3)-C(14)$ & $1.31(2)$ & $C(11)-C(12)$ & $1.44(2)$ \\
\hline$N(4)-C(17)$ & $1.32(2)$ & $C(14)-C(15)$ & $1.38(3)$ \\
\hline$N(4)-C(20)$ & $1.31(2)$ & $C(15)-C(16)$ & $1.40(2)$ \\
\hline$N(5)-C(13)$ & $1.32(2)$ & $\mathrm{C}(18)-\mathrm{C}(19)$ & $1.35(3)$ \\
\hline$N(5)-C(16)$ & $1.33(2)$ & $C(19)-C(20)$ & $1.41(2)$ \\
\hline$N(6)-C(17)$ & $1.35(2)$ & & \\
\hline \multicolumn{4}{|c|}{ Bond angles (deg) } \\
\hline $\mathrm{S}(1)-\mathrm{Cd}-\mathrm{S}(2)$ & $116.2(2)$ & $C(13)-N(5)-C(16)$ & $116(1)$ \\
\hline $\mathrm{S}(1)-\mathrm{Cd}-\mathrm{N}(1)$ & $147.9(2)$ & $C(17)-N(6)-C(18)$ & $116(1)$ \\
\hline$S(1)-C d-N(2)$ & $99.8(2)$ & $N(1)-C(1)-C(2)$ & $124(1)$ \\
\hline $\mathrm{S}(1)-\mathrm{Cd}-\mathrm{N}(3)$ & $62.8(3)$ & $\mathrm{S}(1)-\mathrm{C}(13)-\mathrm{N}(3)$ & $114.2(9)$ \\
\hline$S(1)-C d-N(4)$ & $94.3(3)$ & $\mathrm{S}(1)-\mathrm{C}(13)-\mathrm{N}(5)$ & $121(2)$ \\
\hline $\mathrm{S}(2)-\mathrm{Cd}-\mathrm{N}(1)$ & $90.8(2)$ & $N(3)-C(13)-N(5)$ & $125(2)$ \\
\hline$S(2)-C d-N(2)$ & $132.9(2)$ & $N(3)-C(14)-C(15)$ & $126(1)$ \\
\hline $\mathrm{S}(2)-\mathrm{Cd}-\mathrm{N}(3)$ & $126.3(3)$ & $C(14)-C(15)-C(16)$ & $114(1)$ \\
\hline $\mathrm{S}(2)-\mathrm{Cd}-\mathrm{N}(4)$ & $61.4(3)$ & $N(5)-C(16)-C(15)$ & $124(1)$ \\
\hline $\mathrm{N}(1)-\mathrm{Cd}-\mathrm{N}(2)$ & $69.4(3)$ & $S(2)-C(17)-N(4)$ & $117.0(9)$ \\
\hline $\mathrm{N}(1)-\mathrm{Cd}-\mathrm{N}(3)$ & $87.6(3)$ & $\mathrm{S}(2)-\mathrm{C}(17)-\mathrm{N}(6)$ & $119(2)$ \\
\hline$N(1)-C d-N(4)$ & $114.8(3)$ & $\mathrm{N}(4)-\mathrm{C}(17)-\mathrm{N}(6)$ & $124(1)$ \\
\hline$N(2)-C d-N(3)$ & $96.1(3)$ & $N(6)-C(18)-C(19)$ & $124(1)$ \\
\hline $\mathrm{N}(2)-\mathrm{Cd}-\mathrm{N}(4)$ & $86.1(3)$ & $C(18)-C(19)-C(20)$ & $114(2)$ \\
\hline $\mathrm{N}(3)-\mathrm{Cd}-\mathrm{N}(4)$ & $157.2(3)$ & $N(4)-C(20)-C(19)$ & $123(2)$ \\
\hline$C(13)-N(3)-C(14)$ & $115(2)$ & $C(17)-N(4)-C(20)$ & $120(1)$ \\
\hline
\end{tabular}

Table V. Selected bond distances and angles $^{\mathrm{a}}$ for $\left[\mathrm{Cd}(\mathrm{pymt})_{2}\right.$ phen].

\begin{abstract}
${ }^{a}$ Estimated standard deviations in the least significant digits are given in parentheses.
\end{abstract}

with pymt $^{-}$and pyt $^{-}$bidentate ligands are very similar: for example, in $\left[\mathrm{Ni}(\mathrm{pyt})_{3}\right]^{-}$and [Ni(pymt $\left.)_{3}\right]^{-}$anions [25] the $\mathrm{Ni}-\mathrm{S}$ bond lengths are $2.518-2.541$ and $2.460-2.545 \AA$; in $\left[\mathrm{Fe}(\text { pyt })_{3}\right]^{-}$ [26] and $\left[\mathrm{Fe}(\text { pymt })_{3}\right]^{-}$anions [6, 7] 2.568-2.589 and $2.523-2.537 \AA$; and in [Ni(pyt $)_{2} \cdot$ bipy] [11] and [Ni(pymt) $)_{2}$ bipy] [12] 2.475-2.495 and 2.480$2.523 \AA$. The difference between the $\mathrm{Cd}-\mathrm{S}$ lengths in $\left[\mathrm{Cd}(\text { pymt })_{2} \cdot\right.$ phen] and the $\mathrm{Zn}-\mathrm{S}$ lengths in [ $\mathrm{Zn}(\mathrm{pyt})_{2} \cdot$ phen] can therefore be expected to be approximately the same as the difference between the van der Waals radii [27] of $\mathrm{Cd}(1.58 \AA)$ and $\mathrm{Zn}$ (1.39 $\AA$ ) which is close to $0.2 \AA$. Differences of this order have indeed been observed for $\mathrm{Cd}$ and $\mathrm{Zn}$ complexes with thiolate ligands, such as $\left[\mathrm{M}(\mathrm{SPh})_{4}\right]^{2-}$ and $\mathrm{M}\left[(\mathrm{SPh})_{2}(1-\mathrm{Me}-\mathrm{imid})_{2}\right](\mathrm{Cd}-\mathrm{S}$, 2.46-2.54 $\AA$; $\mathrm{Zn}-\mathrm{S}, 2.30-2.38 \AA$ ) [24, 28]. Consequently, the $\mathrm{Cd}-\mathrm{S}$ distance in $\left[\mathrm{Cd}(\text { pymt })_{2}\right.$ phen] is unusually short.
The Cd-Npymt bond distances, 2.42(2) and 2.53(2) $\AA$, are significantly larger than those reported in the tetrahedral $\left[\mathrm{Cd}\right.$ (thiamine) $\left.\mathrm{Cl}_{3}\right] \cdot 0.6 \mathrm{H}_{2} \mathrm{O}$ [29], 2.239(2) $\AA$, and even slightly greater than those observed in other octahedral cadmium complexes involving heterocyclic nitrogen donor ligands: for example $2.310(3) \AA$ in bis( $\mathrm{N}$-isonicotinato)tetraquo-cadmium(II) [30]; 2.336(5) $\AA$ in diformatodiaquobis(nicotinamide) cadmium(II) [31]; $2.35 \AA$ in $\mathrm{CdCl}_{2} \cdot 2$ py [32] and $2.23(2) \AA$ in pyridine2-carboxylate cadmium(II) [33].

The $\mathrm{Cd}-\mathrm{S}$ and $\mathrm{Cd}-\mathrm{Npymt}$ bond lengths in the chelate rings are all greater than the corresponding distances generally observed in other octahedral compounds containing the pyrimidine-2-thiolato moiety and, consistent with these increased bond lengths, the $\mathrm{S}-\mathrm{Cd}-\mathrm{Npymt}$ chelate bite angles are narrower $\left(\mathrm{ca} .62^{\circ}\right.$ in $\left[\mathrm{Cd}(\text { pymt })_{2} \cdot\right.$ phen]) than the $\mathrm{S}-\mathrm{M}-\mathrm{Npymt}$ angles of $66-72^{\circ}$ in tris(4,6-dime- 
thylpyrimidine-2-thiolato)cobalt(III) [34] (Co-S, $2.252-2.269 \AA$; Co-Npymt, $1.975-1.986 \AA)$; in tetramethylammonium tris(pyrimidine-2-thiolato)ferrate(III) $[6,7] \quad(\mathrm{Fe}-\mathrm{S}, \quad 2.524-2.536 \AA$; Fe-Npymt, 2.149-2.180 $)$; tetraphenylphosphonium tris(pyrimidine-2-thiolato)nickelate(II) [25] $(\mathrm{Ni}-\mathrm{S}, 2.480-2.523 \AA$; Ni-Npymt, 2.025$2.053 \AA$ ); and 2,2'-bipyridinebis(pyrimidine2-thiolato)nickel(II) [12].

The Cd-Nphen bond distances in the complex are 2.349(9) and 2.36(1) $\AA$, which are close to those reported [35] for [Cd(acac $)_{2} \cdot$ phen] $(2.368(2) \AA)$ and $\left[\mathrm{Cd}\left(\mathrm{CF}_{3} \mathrm{COCHCOC} \mathrm{H}_{5}\right)_{2} \cdot\right.$ phen] $(2.32(3) \AA)$.

The angle $\mathrm{N}(3)-\mathrm{Cd}-\mathrm{N}(4)$ between the mutually "trans" nitrogen atoms is $157.2(3)^{\circ}$, while the angle $\mathrm{S}(1)-\mathrm{Cd}-\mathrm{S}(2)$ between the mutually "cis" sulphur atoms is $116.2(2)^{\circ}$. The angles $\mathrm{S}(1)-\mathrm{Cd}-\mathrm{N}(4)$ and $\mathrm{S}(2)-\mathrm{Cd}-\mathrm{N}(3)$ are $94.3(3)^{\circ}$ and $126.3(3)^{\circ}$, respectively, very different from those expected for a regular octahedral structure. As far as we know, all other structurally characterized octahedral complexes with two chelated pymt ${ }^{-}$or pyt $^{-}$ligands have trans sulphur atoms and cis nitrogen atoms $[10-12,36]$, making $\left[\mathrm{Cd}(\mathrm{pymt})_{2} \cdot\right.$ phen] the first in which it is the sulphur atoms that are "cis".

Each of the pyrimidine-2-thiolato ligands is planar within experimental error. The interplanar angle between these two bidentate ligands is $54.88^{\circ}$, which is very different from that observed in $\left[\mathrm{Ni}(\text { pymt })_{2} \cdot\right.$ bipy] $\left(82.4^{\circ}\right)$ [12].

The average $\mathrm{C}-\mathrm{S}$ and $\mathrm{C}-\mathrm{N}$ bond lengths of the pyrimidine-2-thiolato ligands are 1.71(1) and 1.33(2) $\AA$ respectively. These values are similar to those observed in other pyrimidine-2-thiolato complexes, suggesting a $\mathrm{C}-\mathrm{N}$ bond order of $c a$. 1.5 and that these ligands are bonded as thiolates, with very little contribution from the thione form [7].

The phenanthroline ligand is also essentially planar; the bond lengths and angles within the ligand are similar to those found in other phenanthroline complexes, and are not discussed further. Moreover, the small $\mathrm{N}(1)-\mathrm{Cd}-\mathrm{N}(2)$ bite of the 1,10-phenanthroline, $69.4(3)^{\circ}$, is hardly different from that reported for other bidentate 1,10-phenanthroline cadmium complexes [19, 35].

\section{Spectroscopic properties}

The IR spectra of $\left[\mathrm{M}(\text { pymt })_{2}\right](\mathrm{M}=\mathrm{Zn}, \mathrm{Cd})$ compounds show that the free pyrimidine-2-thione
$v(\mathrm{NH})$ at $2950 \mathrm{~cm}^{-1}$, [37] is absent from the complexes, indicating that deprotonation of this group has occurred and therefore that the ligand is coordinated in the thiol form. Moreover, the ring stretching, $\mathrm{C}-\mathrm{H}$ in plane deformation and ring breathing ligand bands of the complexes appear close to those observed for 1,10-phenanthroline bis(pyrimidine-2-thionato)cadmium(II), whose structure has been determined by X-ray diffraction. The coordination of the pyrimidine2-thionato ligand must therefore be similar in these compounds, with the metal binding through the sulphur and one of the nitrogen atoms. Accordingly, we suggest that the complexes $\left[\mathrm{M}(\text { pymt })_{2}\right]$ have either tetrahedral geometry or a polymer structure similar to that of $\left[\mathrm{Cd}(\mathrm{pyt})_{2}\right]$ [38].

In the complexes with bipy or phen, IR bands typical of these bases are also observed. The bands at $c a .1510,845$ and $725 \mathrm{~cm}^{-1}$ in the phenanthroline complexes and at 1465,775 and $730 \mathrm{~cm}^{-1}$ in the 2,2'-bipyridine complexes are characteristic of these ligands when complexed [39]. Consequently, octahedral geometry is proposed for compounds $\left[\mathrm{M}(\text { pymt })_{2} \mathrm{~L}^{\prime}\right],(\mathrm{L}=$ bipy, phen $)$.

The ${ }^{1} \mathrm{H}$ NMR spectra of the complexes in DMSO were recorded at $25^{\circ} \mathrm{C}$; the results are summarized in Table VI. The ${ }^{1} \mathrm{H}$ NMR spectra of the two parent complexes, $\left[\mathrm{Zn}(\text { pymt })_{2}\right]$ and $\left[\mathrm{Cd}(\text { pymt })_{2}\right]$ show two signals, one a doublet at about $8.2 \mathrm{ppm}$ attributale to hydrogens 4 and 6 , and the other a triplet at about $6.8 \mathrm{ppm}$ attributable to hydrogen 5 .

The ${ }^{1} \mathrm{H}$ NMR spectra of the complexes

$\left[\mathrm{Cd}(\text { pymt })_{2} \cdot\right.$ bipy] and $\left[\mathrm{Zn}(\text { pymt })_{2} \cdot\right.$ bipy] exhibit four distinct and widely separated signals of equal intensity assignable to the four non-equivalent hydrogens of bipy. The downfield shift of the signal attributable to the $3,3^{\prime}$ protons and the upfield shift of that of the 6,6'protons can be taken as indication of the coordination of bipy [40]. In addition, two signals due to the pyrimidine hydrogens $\mathrm{H}_{4}$, $\mathrm{H}_{6}$ and $\mathrm{H}_{5}$ are observed with intensities with a ratio of $2: 1$.

The ${ }^{1} \mathrm{H}$ NMR spectra of $\left[\mathrm{Cd}(\text { pymt })_{2} \cdot\right.$ phen] and $\left[\mathrm{Zn}(\text { pymt })_{2} \cdot\right.$ phen] show four signals for the 1,10 phenanthroline hydrogens and two signals for the pyrimidine hydrogens $\mathrm{H}_{4}, \mathrm{H}_{6}$ and $\mathrm{H}_{5}$. The signals attributable to the 2,9 and 3,8 protons of phen undergo a small downfield shift with respect to the 
Table VI. ${ }^{1} \mathrm{H}$ NMR data of the complexes in $\mathrm{DMSO}^{\mathrm{a}}$.

\begin{tabular}{|c|c|c|c|c|c|c|}
\hline \multirow[b]{2}{*}{ Complex } & \multicolumn{3}{|c|}{ Pyrimidine ring } & \multicolumn{3}{|c|}{ phen (bipy) ring } \\
\hline & $\mathrm{H}_{4}, \mathrm{H}_{6}$ & $\mathrm{H}_{5}$ & $\mathrm{H}_{2,9}\left(\mathrm{H}_{3,3^{3}}\right)$ & $\mathrm{H}_{4,7}\left(\mathrm{H}_{4,4^{\prime}}\right)$ & $\mathrm{H}_{5,6}\left(\mathrm{H}_{5,5^{\prime}}\right)$ & $\left.\mathrm{H}_{3,8} \mathrm{H}_{6,6^{6}}\right)$ \\
\hline pymtH & $8.28 \mathrm{~d}(2)$ & $6.83 \mathrm{dd}(1)$ & & & & \\
\hline $\mathrm{Zn}(\mathrm{pymt})_{2}$ & $8.28 \mathrm{~d}(2)$ & $6.90 \mathrm{t}(1)$ & & & & \\
\hline $\mathrm{Zn}(\text { pymt })_{2}$ bipy & $8.24 \mathrm{~d}(2)$ & $6.86 \mathrm{t}(1)$ & $8.81(1)$ & $8.57(1)$ & $8.15(1)$ & $7.65(1)$ \\
\hline $\mathrm{Zn}(\mathrm{pymt}){ }_{2}$ phen & $8.20 \mathrm{~d}(2)$ & $6.84 \mathrm{t}(1)$ & $9.27(1)$ & $8.90(1)$ & $8.27(1)$ & $8.09(1)$ \\
\hline $\mathrm{Cd}(\text { pymt })_{2}$ & $8.20 \mathrm{~d}(2)$ & $6.87 \mathrm{t}(1)$ & & & & \\
\hline $\mathrm{Cd}(\text { pymt })_{2}$ bipy & $8.20 \mathrm{~d}(2)$ & $6.85 \mathrm{t}(1)$ & $8.74(1)$ & $8.45(1)$ & $8.04(1)$ & $7.55(1)$ \\
\hline $\mathrm{Cd}($ pymt $){ }_{2}$ phen & $8.20 \mathrm{~d}(2)$ & $6.85 \mathrm{t}(1)$ & $9.28(1)$ & $8.90(1)$ & $8.29(1)$ & $8.12(1)$ \\
\hline
\end{tabular}

\footnotetext{
${ }^{a}$ Resonance signals reported in ppm downfield from $\mathrm{Me}_{4} \mathrm{Si}$. Key: d, doublet; t, tripelt. Relative integrated intensi-
} ties in parentheses.

free ligand. This shift has been taken as proof of the coordination of phen [41]. These results show that in solution the complexes retain the structure observed in the solid state (vide supra).

However, according to this structure, hydrogens 4 and 6 of the pyrimidine ring are not equivalent, and the NMR spectrum should consequently show two different signals for them. Their equivalence would be explained if coordination to the metal alternates between nitrogen 1 and 3. To investigate this hypothesis, the NMR spectrum of $\left[\mathrm{Cd}(\text { pymt })_{2}\right.$ phen] was recorded in $\mathrm{CDCl}_{3}$ from room temperature to $218 \mathrm{~K}$. At the latter temperature the signal of $\mathrm{H}_{5}$ is a double doublet, and the signals of protons $\mathrm{H}_{4}$ and $\mathrm{H}_{6}$ are different, partially overlapping each other and one of the phenanthroline signals. Thus hydrogens $\mathrm{H}_{4}$ and $\mathrm{H}_{6}$ are no longer equivalent at $218 \mathrm{~K}$. At low temperature, the phenanthroline signals also change, with all the hydrogens non-equivalent. The signal of the phenanthroline protons $\mathrm{H}_{5}$ and $\mathrm{H}_{6}$, for example, is a sharp singlet at room temperature, but an $\mathrm{AB}$ system at $218 \mathrm{~K}$. The non-equivalence of the phenanthroline hydrogens is to be expected in view of the solid state structure of the compound.

We thank the Xunta de Galicia

(XUGA 20306 B91), Spain, for financial support.
[1] a) J. A. Carbon, L. Hung, and D. Jones, Proc. Nat. Acad. Sci. USA. 53, 979 (1965);

b) E. Sheffer and H. G. Mautner, J. Am. Chem. Soc. 89, 1249 (1967);

c) J. A. Carbon, H. David, and M. H. Studier, Science 161, 1146 (1968).

[2] C. Lecomte, St. Skoulika, P. Aslanidis, P. Karagiannidis, and St. Papastefanou, Polyhedron 8, 1103 (1989).

[3] J. Abbot, D. M. L. Goodgame, and I. Jeeves, J. Chem. Soc. Dalton 1978, 880.

[4] D. M. L. Goodgame, A. M. Z. Slawin, D. J. Williams, and P. W. Zard, Inorg. Chim. Acta 148, 5 (1988).

[5] a) F. A. Cotton and W. H. Ilsley, Inorg. Chim. Acta 59, 213 (1982);

b) F. A. Cotton and W. H. Ilsley, Inorg. Chem. 20, 614 (1981).

[6] S. G. Rosenfield, P. K. Mascharak, and S. K. Arora, Inorg. Chim. Acta 129, 39 (1987).

[7] I. A. Latham, G. J. Leigh, Ch. J. Pickett, G. Huttner, I. Jibrill, and J. Zubieta, J. Chem. Soc. Dalton Trans. 1986, 1181.
[8] D. M. L. Goodgame, R. W. Rollins, and A. C. Skapski, Inorg. Chim. Acta 83, L 11 (1984).

[9] A. Sousa, unpublished results.

[10] M. L. Durán, J. Romero, J. A. García-Vázquez, R. Castro, A. Castiñeiras, and A. Sousa, Polyhedron 10, 197 (1991)

[11] R. Castro, M. L. Durán, J. A. García-Vázquez, J. Romero, A. Sousa, A. Castiñeiras, W. Hiller, and J. Strähle, J. Chem. Soc. Dalton Trans. 1990, 531.

[12] R. Castro, M. L. Durán, J. A. García-Vázquez, J. Romero, A. Sousa, A. Castiñeiras, W. Hiller, and J. Strähle, Z. Naturforsch. 45b, 1632 (1990).

[13] J. J. Habeeb, D. G. Tuck, and F. H. Walters, J. Coord. Chem. 8, 27 (1978).

[14] N. Walker and D. Stuart, Acta Crystallogr. A39, 158 (1983).

[15] W. H. Zachariasen, Acta Crystallogr. 16, 1139 (1963).

[16] C. M. Sheldrick, SHELXS 86, A program for the solution of crystal structures from X-ray diffraction data, University of Göttingen, Germany (1986).

[17] B. A. Frenz, The Enraf-Nonius CAD4-SDP. A Real-Time System for Concurrent X-ray. Data Col- 
lection and Crystal Structure Solution. In computing in Crystallography, edited by H. Schenk, R. Olthof-Hazekamp, H. van Koningsveld and G. C. Bassi, Delft Univ. Press (1976).

[18] E. Keller, SCHAKAL, A program for plotting molecular and crystal structures, University of Freiburg, Germany.

[19] C. L. Raston and A. H. White, Aust. J. Chem. 29, 739 (1976).

[20] J. A. Mc Cleverty, S. Gill, R. S. Z. Kowalski, N. A. Bailey, H. Adams, K. W. Lumbard, and M. A. Murphy, J. Chem. Soc. Dalton Trans. 1982, 493.

[21] S. J. Black, F. W. B. Einstein, P. C. Hayes, R. Kumar, and D. G. Tuck, Inorg. Chem. 25, 4181 (1986).

[22] A. Domenicano, L. Torelli, A. Vaciago, and L. Zambonelli, J. Chem. Soc. A 1968, 1351.

[23] V. M. Agre and E. A. Shugan, Kristallografiya 17, 303 (1972).

[24] D. Swenson, N. C. Baenziger, and D. Coucouvanis, J. Am. Chem. Soc. 100, 1932 (1978); D. T. Corwin (Jr.), E. S. Gruff, and S. A. Koch, J. Chem. Soc., Chem. Commun. 1987, 966; N. Ueyama, T. Sugawara, K. Sasaki, A. Nakamura, S. Yamashita, Y. Wakatsuki, H. Yamazaki, and N. Yasuoka, Inorg. Chem. 27, 741 (1988).

[25] S. G. Rosenfield, H. P. Berends, L. Gelmini, D. W. Stephan, and P. K. Mascharak, Inorg. Chem. 26, 2792 (1987).

[26] S. G. Rosenfield, S. A. Swedberg, S. K. Arora, and P. K. Mascharak, Inorg. Chem. 25, 2109 (1986).

[27] A. Bondi, J. Phys. Chem. 68, 441 (1964).

[28] D. T. Corwin (Jr.) and S. A. Koch, Inorg. Chem. 27, 493 (1988).

[29] R. E. Cramer, R. B. Maynard, and J. A. Ibers, J. Am. Chem. Soc. 76, 103 (1981).
[30] M. Biagini, A. Gaetani, C. Guastani, A. Musatti, and M. Nardelli, Gazz. Chim. Ital. 101, 815 (1971).

[31] A. S. Antsyshkina, M. A. Porai-Koshits, M. Khandlovich, and V. N. Ostrikova, Koord. Khim. 7, 461 (1981).

[32] H. Paulus, Z. Anorg. Allg. Chem. 369, 38 (1969).

[33] J. P. Deloume and H. Loiseleur, Acta Crystallogr. B 30, 607 (1974)

[34] B. A. Cartwright, D. M. L. Goodgame, I. Jeeves (Jr.), P. O. Langguth, and A. C. Skapski, Inorg. Chim. Acta 24, L 45 (1977).

[35] L. Bustos, J. H. Green, J. L. Hencher, M. A. Khan, and D. G. Tuck, Can. J. Chem. 61, 2141 (1983).

[36] a) S. R. Fletcher and A. C. Skapski, J. Chem. Soc. Dalton 1972, 635;

b) M. Masaki, S. Matsunami, and H. Ueda, Bull. Chem. Soc. Jpn. 51, 3298 (1978);

c) P. Mura, B. G. Olby, and S. D. Robinson, J. Chem. Soc. Dalton Trans. 1985, 2101; Inorg. Chim. Acta 98, L 21 (1985);

d) A. J. Deeming, M. N. Meah, N. P. Randle, and K. I. Hardcastle, J. Chem. Soc. Dalton Trans. 1989, 2211.

[37] D. N. Sathyanarayana and S. V. K. Raja, Spectrochim. Acta 41 A, 809 (1985).

[38] M. B. Hursthouse, O. F. Z. Khan, M. Mazid, M. Motevalli, and P. O'Brien, Polyhedron 9, 541 (1990).

[39] A. A. Schilt and R. C. Taylor, J. Inorg. Nucl. Chem. 9, 211 (1959); R. G. Inskeep, J. Inorg. Nucl. Chem. 24, 763 (1962).

[40] S. Castellano, H. Günther, and S. Ebersole, J. Phys. Chem. 69, 4166 (1965); H. E. Mabrouk and D. G. Tuck, J. Chem. Soc. Dalton Trans. 1988, 2539.

[41] S. Yamazaki, Polyhedron 4, 1915 (1985). 